\title{
Bloodstream infections and herpesvirus activation following intensive chemother- apy of adult oncohematological patients
}

\author{
Vitaly N. Chebotkevich, Stanislav S. Bessmeltsev, Ekaterina E. Kiseleva, Natalya P. Stizhak, Elena I. Kaytandzhan, Vitaly V. Burylev \\ Russian Research Institute of Hematology and Transfusiology, St. Petersburg; 2nd Sovetskaya St.16, 191024 St. Petersburg, Russia.
}

Professor Vitaly N. Chebotkevich, Russian Research Institute of Hematology and Transfusiology, St. Petersburg; 2nd Sovetskaya St. 16, 191024 St. Petersburg, Russia.
Phone: +7 (812) 717-29-58

Fax: +7 (812) 717-25-50

E-mail: vitnikcheb@mail.ru

\section{Summary}

Intensive cytostatic chemotherapy is a standard strategy for leukemia treatment. Meanwhile, such treatment causes negative effects, i.e., including lymphopenia, granulocytopenia and damage to tissue barriers associated with significant risks of infectious complications, especially, bacterial sepsis and viremia. Our study was aimed for identification of bacteremia and fungemia in oncohematological patients following intensive chemotherapy, and assessment of potential modifying role of herpesvirus infections.

We assessed frequency of infectious complications and their etiological agents in two groups of oncohematological patients treated at the Russian Institute of Hematology and Transfusion, especially focusing on mixed infections. Throat smears, venous blood, as well as urine and sputum specimens were taken for routine bacteriological cultures. Whole blood leukocytes were virologically tested by PCR, using standard examination protocol.

Our first virological study was performed for respiratory infections and included 85 randomly chosen patients. Influenza and parainfluenza viruses, respiratory syncytial virus, rhinovirus, adenovirus were detected in blood of single patients. Meanwhile, herpesviruses were detectable in $42 \%$ proportion of cases, i.e., HSV, EBV, and CMV DNA in blood cells were revealed in 5.2\%, 26.3\%, and $10.5 \%$, respectively. Viral infections were not associated with positive bacteriological findings in this group.
Our group of 33 clinical cases with proven sepsis observed among 64 patients. Generally, Gram-positive species prevailed over Gram-negative bacteria (69.2\% versus $30.8 \%$ ). However, the ratio of detectable Gram-negative flora was found to be increased from $23.1 \%$ to $40.2 \%$ between 2002 and 2013 ( $\mathrm{p}<0.05$ ). Coagulase-negative staphylococci (CoNS) prevailed among Gram-positive microorganisms, in particular, S. epidermidis and S. aureus), whereas Enterobacteriaceae, especially, E.coli, dominated among the Gram-negative bacteria.

Interestingly, 4 of 11 patients with coagulase-negative bacteremia had a concomitant herpesvirus infection: 2 cases were associated with EBV; 1, with CMV, and 1, with HHV6/EBV coinfection. Therefore, a high ratio of viral and bacterial co-infections may be revealed in a number of patients with proven sepsis. Moreover, common reactivation of herpesviruses may cause immunosuppression, or represent additional immunodeficiency markers predictive for bacterial infections at later terms. Therefore, one should take into account their predisposal for severe infectious complications when planning hematopoietic stem cell transplantation (HSCT) for these patients.

\section{Keywords}

Leukemia, lymphoma, intensive chemotherapy, sepsis, viremia, coinfection 


\section{Introduction}

Implementation of modern treatment strategies in leukemia patients, e.g., extensive usage of novel targeted drugs have resulted into sufficient increase of complete remission rates and higher survival rates. However, introduction of the new-generation treatment is associated with additional adverse effects including granulocytopenia and injuries of tissue barriers (skin and mucosae). These side effects cause significant risks for infectious complications, up to bloodstream infections and generalized septic conditions. Spectrum of detectable microbial pathogens in the hematooncological patients was sufficiently changed over last decades. I.e., Gram-positive microflora predominated in the 90's, making up to $70 \%$ of the microbial findings [13]. More recently, however, an increasing proportion of Gram-negative infections was registered in the immunocompromised patients [4]. Potential role of viral pathogens, especially, herpesviruses, in development of bloodstream infections is also poorly understood, despite their common reactivation during mixed infections in hemato-oncological patients. [5].

At present time, a septic state is determined as a generalized inflammatory response to infectious pathogens of different origin, either bacterial, fungal, parasitic, or viral etiology. Clinical criteria of the sepsis diagnostics first approved in 1992, are well known and applicable worldwide [6]. In accordance with these criteria, sepsis is considered a systemic inflammation syndrome in response to infectious factor(s).

Viral infections are widely known to play a significant role in genesis of infectious complications in patients with hemato-oncological disorders. In most cases, the virus-related conditions are caused by reactivation of latent virus(es), whereas reinfections seems to be more rare. Viral reactivation is most commonly detected for herperviruses, e.g., cytomegalovirus (CMV), Herpes Simplex types 1 and 2 (HSV $1 / 2$ ), Varicella Zoster virus (VZV). CMV is considered a most common risk factor for life-threatening infections in hemato-oncology patients However, some other viruses (adenovirus, hepatitis B virus) may also undergo reactivation in immunocompromised patients. In particular, respiratory viral infections are common to this cohort.
Before implementation of pre-emptive antiviral therapies in oncohematology, CMV infection was associated with severe organ affection and high mortality rates among recipients of hematopoietic stem cells (HSCs). In our previous experience [11], mortality of the patients with clinical CMV disease was $32 \%$ (7/22). Most cases of CMV disease were registered following allogeneic HSCT. Noteworthy, the CMV disease was accompanied by different aggravating conditions (bacterial sepsis, graft rejection, multi-organ failure, GvHD (graft versus host diseases), thus presuming severity of the condition and worse prognosis. CMV disease following auto-HSCT, was associated with retarded engraftment. Meanwhile, only $5 \%(3 / 66)$ of leukemia patients who received intensive chemotherapy have developed CMV disease (hemorrhagic cystitis, cytopenic fever, interstitial pneumonia). Anyway, clinically sound CMV reactivation may prevent a full-scale chemotherapy, thus suggesting worse prognosis for primary malignancy.

Modern approaches to management of CMV infection allowed to decrease risk of fatalities in this cohort. There exist, however, some open questions concerning pathogenesis of $\mathrm{CMV}$ infections and their role as an underlying factor for development of other viral and microbial infections, e.g., respiratory conditions.

The aim of our study was to assess some features of emerging infectious complications in immunocompromised oncohematological patients and possible role of herpesviruses in their genesis.

\section{Patients and methods}

The first case series included eighty-five randomly chosen adult patients with oncohematological disorders (Table 1). We assessed general frequency of infectious complications and their etiological agents focusing, mainly, on mixed infections of bacterial, fungal and viral origin. Throat smears, venous blood, as well as urine and sputum specimens were taken for bacteriology and virological testing under standard examination protocol at the Hematology Clinics.

Table 1. Clinical and demographic characteristics of the patients in group 1

\begin{tabular}{|c|c|c|c|c|}
\hline Clinical diagnosis & Number of patients & Males & Females & Median age, years \\
\hline Multiple myeloma & 15 & 5 & 10 & $26-70$ \\
\hline $\begin{array}{l}\text { Acute leukemia: } \\
\text { Acute lymphoblastic leu- } \\
\text { kemia (ALL) }\end{array}$ & 2 & 1 & 1 & $18-52$ \\
\hline $\begin{array}{l}\text { Acute myeloid leukemia } \\
\text { (AML) }\end{array}$ & 10 & 5 & 5 & $28-73$ \\
\hline Total: & 12 & & & \\
\hline
\end{tabular}




\begin{tabular}{|l|l|l|l|l|}
\hline Clinical diagnosis & Number of patients & Males & Females & Median age, years \\
\hline $\begin{array}{l}\text { chronic lymphocytic leu- } \\
\text { kemia (CLL): }\end{array}$ & 33 & 19 & 14 & $46-81$ \\
$\begin{array}{l}\text { Chronic myeloid leukemia } \\
\text { (CML), chronic phase }\end{array}$ & 4 & 3 & 1 & $34-52$ \\
$\begin{array}{l}\text { Primary myelofibrosis } \\
\text { Essential thrombocythemia }\end{array}$ & 1 & 1 & - & 60 \\
Total: & 39 & 1 & - & 44 \\
\hline Malignant lymphomas & 19 & & & \\
\hline Total & 85 & 9 & 10 & $27-66$ \\
\hline
\end{tabular}

As seen from Table 1, $80 \%$ of the patients were admitted with CLL ( $n=33)$, malignant lymphomas ( $n=19)$, multiple myeloma $(n=15)$. Acute leukemias made only $12 \%$ of the group.

All the patients received specific cytostatic therapy according to their primary diagnosis, i.e., cytostatic drugs, monoclonal antibodies, proteasome inhibitors, immunomodulatory drugs, tyrosine kinase inhibitors, hypomethylating drugs. Appropriate treatment protocols were as follows: $7+3$ for AML; 7+3+ATRA for acute promyelocytic leukemia; VRP-prolong for ALL; R-CHOP for non-Hodgkin's lymphoma etc.

Among these patients, infectious complications during chemotherapy or after its completion have been revealed in 50 cases ( $63 \%$ of total). Thirty-five patients who did not show clinical signs of infection comprised a comparison group. The patients with clinical infections were administered empirical therapy with broad-spectrum antibiotics. The drug therapy was corrected according to in vitro antibiotic sensitivity testing.

To assess rates of clinical conditions and outcomes of the bloodstream infections, as well as to specify possible complicating role of herpesviruses, we carried out an additional retrospective analysis of 64 clinical cases of different oncohematological disorders treated at the Department of Hematology of our Institute within 2005-2013 (Series 2, Table 2). The patients' data were collected from clinical charts. Primary microbiological information was retrieved from the laboratory worksheets. All positive hemocultures and other microbiological findings were documented in worksheets.

We have analyzed individual data on blood bacteriological testing in patients admitted to our Department of Hematology and treated for different myelo- and lymphoproliferative disorders (acute and chronic leukemias, multiple myeloma, non-Hodgkin's lymphomas, myelodysplastic syndrome).

Table 2. Clinical and demographic characteristics of the patients (group 2)

\begin{tabular}{|l|l|l|l|l|}
\hline Clinical diagnosis & Number of patients & Males & Females & Median age, years \\
\hline Multiple myeloma & 6 & 3 & 3 & $58(44-79)$ \\
\hline ALL & 8 & 3 & 5 & 34 (19-65) \\
\hline AML & 27 & 11 & 16 & $52(22-74)$ \\
\hline CLL & 8 & 7 & 1 & $53(46-72)$ \\
\hline CML & 5 & 4 & 1 & $45(42-66)$ \\
\hline Non-Hodgkin's lymphoma & 8 & 7 & 1 & $45(18-71)$ \\
\hline Myelodysplastic syndrome & 2 & 1 & 1 & $62(56-67)$ \\
\hline Total & 64 & 36 & 28 & \\
\hline
\end{tabular}

Primary diagnosis in the patients was based on routine hematological examinations, i.e., blood counts, bone marrow punctures, trephine biopsies, cytogenetic, molecular biology, biochemical and immunological parameters. Multiple my- eloma (MM) was confirmed by monoclonal protein revealed in blood serum or urine, along with lytic skeletal lesions detected upon X ray radiography. Diagnostics of lymphomas and chronic lymphatic leukemia included abdominal and 
retroabdominal ultrasonography, CT scanning, NMR and PET (if indicated), as well as immunohistochemical examination of affected lymph nodes, blood and marrow. CML diagnosis was based on detection of $\mathrm{Ph}^{\text {-chromosome and }}$ chymeric $B C R / A B L$. Phenotyping in acute leukemia was performed using cytochemical and immunological tests.

Antibacterial therapy was started immediately upon diagnosis of infection. First-line therapy was usually performed at empirical basis, in accordance with conventional approaches and at average therapeutic doses [3].

Due to severe clinical state of the patients, antimicrobial therapy usually included two broad-spectrum antibiotics (third- and fourth-generation cephalosporins, aminoglycosides, fluoroquinolones), sometimes combined with metronidazole. Two or three days later, upon getting data on antibiotics resistance, the antimicrobial therapy could be modified, carbapenems were added in the most severe cases. Immune correction included immunoglobulin-based drugs (Pentaglobin, Octagam), being an obligate therapeutic component. When detecting herpesviruses (EBV, HSC-1/2, HHV6, or CMV) the therapy was accomplished by antiviral drugs, i.e., Acyclovir or Valacyclovir (for CMV treatment).

Diagnostics of septic conditions was based on clinical data (evidence of primary site and port of infection, septic syndrome, secondary sites of infection), and confirmed by the pathogen isolation in culture. During Grade IV neutropenia $\left(<0.5 \times 10^{9} / \mathrm{L}\right)$, clinical diagnosis of infectious conditions was suggested upon single increase of the body temperature $\left(>38.0^{\circ} \mathrm{C}\right)$, or repeated hyperthermia over $38.5^{\circ} \mathrm{C}$ within 24 hours which could not be explained by clinical course of the primary disorder, or by the treatment performed. Systemic inflammatory reaction syndrome was based upon registration of, at least, 2 of 4 following clinical symptoms: [6].

- body temperature $>38{ }^{\circ} \mathrm{C}$, or $<36{ }^{\circ} \mathrm{C}$;

- heart rate $>90$ per minute;

- breathing rate $>20$ per minute, or hyperventilation $\left(\mathrm{pCO}_{2}\right.$ $<32 \mathrm{~mm} \mathrm{Hg}$ )

- peripheral leukocyte counts $>12 \times 10^{9} / \mathrm{L}$, or $<4 \times 10^{9} / \mathrm{L}$, or at $>10 \%$ immature forms.
In most cases, the blood specimens for bacteriological culture were taken 2, 3 or more times. The primary bacterial strain isolated from hemoculture was regarded as the etiological agent. Bacteriological analyses and identification of micromycetes were performed by uniform technique over the entire study period, according to the valid guidelines [15]. Micromycetes were morphologically identified in culture, by evaluating their growth patterns in agar cultures and fluid media. Enzyme activities and filamentation were used for detection of yeast-like microflora. Standard disc diffusion methods were applied to assess antibiotic sensitivity of isolated strains. E test was applied to determine minimal inhibiting concentration (MIC). The test kits were purchased from AB Biodisc (Sweden) [2].

DNA was extracted from peripheral blood leukocytes. For DNA-diagnostics, we used gene-specific PCR with real-time registration at ANK32 thermocycler. Commercial kits for multiplex PCR were from InterLabService (AmpliSens ${ }^{\oplus}$, Moscow, Russia) allowing to detect respiratory viruses (RSV, influenza $\mathrm{A} / \mathrm{B}$ и $\mathrm{A} / \mathrm{H} 1 \mathrm{~N} 1$ sw types) parainfluenza virus (PIV), rhinovirus, adenovirus, coronavirus, metapneumovirus). The herpesvirus panel included Herpes Simplex type 1 and 2 (HSV); Cytomegalovirus (CMV); Epstein-Barr virus (EBV), and Human Herpesvirus type 6 (HHV6), as well as Clamydophila pneumoniae and Mycoplasma pneumoniae. PCR techniques were performed according to manufacturer instructions. The studies were performed at an. The declared analytical sensitivity for the test systems was $500 \ldots 1000$ copies/mL for HSV $1 / 2$, and $5 \times 10^{5}$ per $10^{5}$ leukocytes for EBV, CMV, and HHV type 6.

Statistical evaluation of the data was performed by means of STATISTICA 6.0 software, using $\chi 2$ and Student criteria. Correlation quotients and their significance were determined by Spearman criterion. The differences were considered significant at $\mathrm{P}<0.05$.

\section{Results}

Our primary task was to evaluate frequencies of viral infections in the patients treated by intensive cytostatic therapy. Results of the virological study for Group 1 (herpesviruse and respiratory infections) are shown in Table 3.

Table 3. Detection frequency of viral pathogens among patients with infectious complications $(n=50)$

\begin{tabular}{|c|c|c|c|c|c|c|}
\hline \multirow[t]{3}{*}{ Viral species } & \multicolumn{6}{|l|}{ Clinical diagnosis } \\
\hline & \multirow{2}{*}{$\begin{array}{l}\text { Multiple myeloma } \\
(n=9)\end{array}$} & \multicolumn{2}{|c|}{ Acute leukemia } & \multicolumn{2}{|c|}{ Chronic leukemia } & \multirow{2}{*}{$\begin{array}{l}\text { Non-Hodgkin's } \\
\text { lymphoma (NHL) } \\
(\mathrm{n}=11)\end{array}$} \\
\hline & & ALL $(n=2)$ & $\operatorname{AML}(n=6)$ & CLL (n=19) & CML $(n=3)$ & \\
\hline Respiratory synticial virus (RSV) & 0 & 0 & 1 & 1 & 0 & 0 \\
\hline Influenza A & 2 & 0 & 0 & 0 & 0 & 2 \\
\hline Influenza B & 0 & 0 & 0 & 0 & 0 & 0 \\
\hline Influenza $\mathrm{A} / \mathrm{HIN1}_{\mathrm{sw}}$ & 0 & 0 & 0 & 1 & 1 & 1 \\
\hline
\end{tabular}




\begin{tabular}{|c|c|c|c|c|c|c|}
\hline \multirow[t]{3}{*}{ Viral species } & \multicolumn{6}{|l|}{ Clinical diagnosis } \\
\hline & \multirow{2}{*}{$\begin{array}{l}\text { Multiple myeloma } \\
(\mathrm{n}=9)\end{array}$} & \multicolumn{2}{|c|}{ Acute leukemia } & \multicolumn{2}{|c|}{ Chronic leukemia } & \multirow{2}{*}{$\begin{array}{l}\text { Non-Hodgkin's } \\
\text { lymphoma (NHL) } \\
(\mathrm{n}=11)\end{array}$} \\
\hline & & ALL $(n=2)$ & $\operatorname{AML}(n=6)$ & CLL (n=19) & CML $(n=3)$ & \\
\hline Parainfluenza 1 & 0 & 0 & 0 & 0 & 0 & 0 \\
\hline Parainfluenza 2 & 0 & 0 & 0 & 0 & 0 & 1 \\
\hline Parainfluenza 3 & 1 & 0 & 1 & 0 & 0 & 1 \\
\hline Parainfluenza 4 & 0 & 0 & 0 & 0 & 0 & 0 \\
\hline Rhinoviruses & 2 & 1 & 0 & 6 & 0 & 2 \\
\hline Adenoviruses & 0 & 0 & 0 & 0 & 0 & 0 \\
\hline Coronaviruses & 1 & 0 & 0 & 2 & 0 & 0 \\
\hline Metapneumovirus & 0 & 0 & 0 & 1 & 0 & 0 \\
\hline Bocavirus & 0 & 0 & 0 & 0 & 0 & 1 \\
\hline Chlamydophila pneumoniae & 0 & 0 & 0 & 0 & 0 & 0 \\
\hline Mycoplasma pneumoniae & 0 & 1 & 0 & 1 & 0 & 0 \\
\hline
\end{tabular}

RSV infection manifesting with fever was found in two patients (association with M.pneumonia in 1 case). Influenza A virus was detected in four patients exhibiting high fever (up to $39.0^{\circ} \mathrm{C}$ ). Three cases of $\mathrm{A} / \mathrm{H} 1 \mathrm{~N} 1_{\text {sw }}$ influenza were observed in 2009. A single patient with CLL treated with Fludarabine+Cyclophosphamide developed a mixed A/H1N1/rhinovirus infection. All the patients with influenza exhibited prolonged fever $\left(<38.6{ }^{\circ} \mathrm{C}\right)$ followed by pneumonia in one case of diffuse large-cell B lymphoma after R-CHOP. PIV 2 and 3 viruses were detectable in four patients accompanied by high fever (up to $38.5^{\circ} \mathrm{C}$ ). In a patient with follicular lymphoma treated by R-CHOP regimen, an association of PIV 3 and bocavirus was found. PIV 3 infection was also registered in AML patient after the $7+3$ chemotherapy and grade severe granulocytopenia followed by acute focal pneumonia. A patient with multiple myeloma after a course of Bortezomib/Dexamethasone developed positivity for PIV 3, with herpes labialis.

Rhinovirus DNA was most common in the studied group, with only mild clinical manifestations, i.e., subfebrile temperature. However, an acute unilateral pneumonia was registered in one ALL patient. An association of rhinovirus with 229E coronavirus was found in one CLL patient. Coronaviruses were detected in 3 cases. The patients exhibited respiratory symptoms (cough, chills), subfebrile state. Metapneumovirus was shown in only 1 case of CLL, manifesting with subfebrility and respiratory symptoms.

The infections were accompanied by herpesvirus reactivation in $42 \%$ of the cases. HSV, EBV, and CMV DNA in blood cells were revealed in $5.2 \%, 26.3 \%$, and $10.5 \%$, respectively. HHV6-specific DNA was not found in any sample from the patients. Antiviral therapy was initiated in patients with herpesvirus-positive blood samples.
Bacteriological study of the throat smears showed prevalence of normal Gram-positive microflora typical to oral microbiota. In 1 case, however, a patient with CLL had E.Coli bacteraemia, in absence of other evident local or systemic pathogens.

In comparison group (infection-free patients), infectious agents were found in 7/35 (20\%) of the cases. I.e., rhinoviruses was revealed in 3 patients, coronaviruses, in 2 cases, and M. pneumoniae, in 2 patients. Anti-infectious treatment was not provided in these cases.

\section{Blood stream infections group: etiological structure}

Our second group included cases with proven sepsis primarily diagnosed by clinical criteria. Table 3 presents data on Gram-positivity and species composition of blood-borne microorganisms in patients with hemoblastoses observed from 1991 to 2013. In general, Gram-positive species prevailed over Gram-negative bacteria (69.2\% versus 30.8\%). However, relative incidence of these microbial classes showed a clear predominance of Gram-negative bacteria over Gram-positives in 1993, 2004, and 2005. The percentage of detectable Gram-negative flora was found to be increased from 23.1\% to $40.2 \%$ between 2002 and 2013 ( $\mathrm{p}<0.05)$. Coagulase-negative staphylococci (CoNS) prevailed among Gram-positive microorganisms, in particular, S. epidermidis and S. aureus), whereas Enterobacteriaceae, especially, E.coli, dominated among the Gram-negative bacteria. Noteworthy, incidence of Pseudomonas spp. and Klebsiella spp. decreased over last decade. 
Table 4. Microorganisms isolated from venous blood of the on-therapy oncohematological patients

\begin{tabular}{|l|l|l|}
\hline \multirow{2}{*}{ Microorganism } & \multicolumn{2}{l|}{ Number of findings } \\
\cline { 2 - 3 } & Absolute & $\%$ of total \\
\hline Gram-negative bacteria & 135 & 30,8 \\
\hline Enterobacteriaceae & 108 & 24.6 \\
\hline Including: & & \\
Escherichia coli & 57 & 13.0 \\
Klebsiella pneumoniae & 6 & 1,4 \\
Salmonella spp. & 5 & 1.1 \\
Serratia marcescens & 2 & 0.4 \\
Others & 38 & 8.7 \\
\hline Gram-negative non-fermenting bacteria & 27 & 6.2 \\
Including: & & 3.0 \\
Pseudomonas spp & 13 & 1.9 \\
Acinetobacter spp & 8 & 0.2 \\
Alcaligenes spp & 1 & 1.1 \\
Others & 5 & 69.2 \\
\hline Gram-positive bacteria & 303 & 48.2 \\
Including: & & 10.6 \\
Staphylococci coagulase-negative & 211 & 2.7 \\
Staphylococcus aureus & 46 & 1.8 \\
Enterococcus spp & 12 & 0.9 \\
Streptococcus viridans & 8 & 5.0 \\
\hline Streptococcus pneumoniae & 4 & 100 \\
\hline Corynebacterium spp & 22 & 438 \\
\hline Total & & \\
\hline
\end{tabular}

A trend towards a higher incidence of Micromycetae among total microflora was also observed. E.g., their proportion in blood cultures was rather low in 2009, followed by increased detection of Micromycetae in 2010, 2011 and 2012 (respectively, 3.3, 9.7, and 5.3\%).

Another task of our study was to specify a potential role of herpesviruses in bacteriaemia observed in leukemia pa- tients. To test this hypothesis, we performed a comparative study of herpesvirus frequency in cases of proven bacterial infections in bloodstream. A comparison group consisted of leukemia patients free of detectable bacteremia. (Table 5). We have revealed a significant increased EBV and CMV incidence in blood of the patients who developed bacteremia, as compared with bacteriemia-free cases.

\section{Table 5. Incidence of herpesvirus DNA in leukemia patients with/without bacteremia}

\begin{tabular}{|l|l|l|l|l|}
\hline \multirow{2}{*}{ Samples under study } & \multicolumn{4}{l|}{ Herpesvirus type, absolute (\%) } \\
\cline { 2 - 5 } & CMV & HSV 1/2 & HHV6 & EBV \\
\hline Leukemia patients n=437 & $21(4.8 \%)$ & $13(3 \%)$ & $48(11 \%)$ & $109(24.9 \%)$ \\
\hline $\begin{array}{l}\text { Leukemia patients with } \\
\text { proven bacterial blood } \\
\text { contamination n=21 }\end{array}$ & $8(38.1 \%)$ & $1(4.8 \%)$ & $2(9.5 \%)$ & $12(51.1 \%)$ \\
\hline $\mathrm{P}$ & $<0.05$ & $>0.05$ & $>0.05$ & $<0.05$ \\
\hline
\end{tabular}




\section{Possible combined effects of blood}

\section{stream infections and viral reactivation} upon clinical outcomes

We have analyzed distinct laboratory features of sepsis in the patients with resistant/relapsing hemoblastoses and lymphomas pre-treated with intensive chemotherapy (Tables 6 and 7).
As seen from Table 6, E.coli was the most common Gram-negative pathogen found in bloodstream (9 episodes). In one patient, E.coli bacteremia was combined with EBV, while the second had CMV reactivation. Other bacteria were more rare (Pseudomonas aeruginosa - 1 case with EBV, HSV $1 / 2$ and HHV6. In 2 cases, bacteremia was caused by Moraxella spp., all the cases were associated with herpesviruses (1, with CMV, and one, with a combination of CMV, HSV 1/2, HHV6, and EBV). Despite massive treatment with the most effective drugs, four patients with Gram-negative sepsis developed septic shock with multi-organ failure. Overall mortality in Gram-negative sepsis was 57\% (8 cases).

Table 6. Clinical data on the patients with bloodstream infections caused by Gram-negative bacteria

\begin{tabular}{|c|c|c|c|c|c|c|c|c|c|}
\hline $\begin{array}{l}\text { Pat. } \\
\text { No. }\end{array}$ & Diagnosis & $\begin{array}{l}\text { Chemo-thera- } \\
\text { py applied }\end{array}$ & $\begin{array}{l}\text { Microbial } \\
\text { species }\end{array}$ & $\begin{array}{l}\text { Virus } \\
\text { detected }\end{array}$ & SIRS & $\begin{array}{l}\text { Sep- } \\
\text { sis }\end{array}$ & $\begin{array}{l}\text { Primary infec- } \\
\text { tion sites }\end{array}$ & $\begin{array}{l}\text { Mucosi- } \\
\text { tis }\end{array}$ & $\begin{array}{l}\text { Out- } \\
\text { come }\end{array}$ \\
\hline 1 & $\begin{array}{l}\text { CLL trans- } \\
\text { for-med to } \\
\text { lymphoma }\end{array}$ & $\begin{array}{l}\mathrm{FC}, \mathrm{FCR}, \\
\mathrm{R}-\mathrm{CHOP}\end{array}$ & E.coli & EBV & + & $\begin{array}{l}\text { Septic } \\
\text { shock }\end{array}$ & NS & - & Lethal \\
\hline 2 & ALL, t(9:22) & $\begin{array}{l}\text { Dasatinib,- } \\
\text { FLAG+ }\end{array}$ & E.coli & CMV & + & + & NS & + & Lethal \\
\hline 3 & CLL & $\mathrm{FC}, \mathrm{FCR}$ & E.coli & No & + & + & NS & - & \\
\hline 4 & AML & $7+3,7+3$ & E.coli & No & + & $\begin{array}{l}\text { Septic } \\
\text { shock }\end{array}$ & NS & + & \\
\hline 5 & AML & $\begin{array}{l}5+2, \text { Decit- } \\
\text { abine }\end{array}$ & E.coli & No & + & + & NS & - & \\
\hline 6 & ALL & $\begin{array}{l}\text { HSCT, MOAD, } \\
\text { VRP-prolong }\end{array}$ & E.coli & No & + & $\begin{array}{l}\text { Septic } \\
\text { shock }\end{array}$ & $\begin{array}{l}\text { Lungs, kid- } \\
\text { neys, } \\
\text { bile ducts }\end{array}$ & - & Lethal \\
\hline 7 & MDS & $\begin{array}{l}\text { Low-dose } \\
\text { Cytosar, } \\
\text { Decitabine }\end{array}$ & E.coli & No & + & + & $\begin{array}{l}\text { Lungs, skin, } \\
\text { soft tissues, } \\
\text { kidneys, } \\
\text { throat and } \\
\text { sinuses }\end{array}$ & - & Lethal \\
\hline 8 & AML & $7+3,7+3$ & E.coli & - & + & + & Lungs & - & \\
\hline 9 & AML & $\begin{array}{l}5+2, \\
\text { Decitabine }\end{array}$ & E.coli & - & + & $\begin{array}{l}\text { Septic } \\
\text { shock }\end{array}$ & Lungs & - & \\
\hline 10 & $\begin{array}{l}\text { CML, blast } \\
\text { crisis }\end{array}$ & $\begin{array}{l}\text { Dasatinib, } \\
5+2\end{array}$ & $\begin{array}{l}\text { Entero- } \\
\text { bac-ter } \\
\text { aerogenes }\end{array}$ & - & + & + & $\begin{array}{l}\text { Lungs, } \\
\text { liver, bile } \\
\text { ducts }\end{array}$ & + & Lethal \\
\hline 11 & AML & $7+3,5+2$ & $\begin{array}{l}\text { Entero- } \\
\text { bac-ter } \\
\text { spp. }\end{array}$ & - & + & + & Lungs & - & Lethal \\
\hline 12 & AML & $\begin{array}{l}7+3,5+2 \\
\text { High-dose } \\
\text { Cytarabine }\end{array}$ & $\begin{array}{l}\text { Moraxella } \\
\text { catarrhalis }\end{array}$ & $\begin{array}{l}\text { EBV, } \\
\text { CMV, } \\
\text { HSV1/2, } \\
\text { HHV6 }\end{array}$ & + & + & Lungs & - & Lethal \\
\hline 13 & $\mathrm{NHL}$ & $\mathrm{R}-\mathrm{CHOP}$ & $\begin{array}{l}\text { Moraxella } \\
\text { catarrhalis }\end{array}$ & $\begin{array}{l}\text { CMV } \\
\text { C.al- } \\
\text { bi-cans }\end{array}$ & + & + & $\begin{array}{l}\text { Lungs, skin } \\
\text { and soft } \\
\text { tissues }\end{array}$ & - & Lethal \\
\hline 14 & CLL & $F C D, F C R$ & $\begin{array}{l}\text { Pseudomo- } \\
\text { nas spp. }\end{array}$ & $\begin{array}{l}\text { EBV, } \\
\text { HHV } 1 / 2, \\
\text { HHV6 }\end{array}$ & + & + & Lungs & - & \\
\hline
\end{tabular}


Table 7. Clinical data on the patients with bloodstream infections caused by Gram-positive bacteria

\begin{tabular}{|c|c|c|c|c|c|c|c|c|c|}
\hline $\begin{array}{l}\text { Pat. } \\
\text { No. }\end{array}$ & Diagnosis & $\begin{array}{l}\text { Chemo-thera- } \\
\text { py applied }\end{array}$ & $\begin{array}{l}\text { Microbial } \\
\text { species }\end{array}$ & $\begin{array}{l}\text { Virus } \\
\text { detect- } \\
\text { ed }\end{array}$ & SIRS & Sepsis & $\begin{array}{l}\text { Primary } \\
\text { infection } \\
\text { sites }\end{array}$ & $\begin{array}{l}\text { Muco- } \\
\text { sitis }\end{array}$ & $\begin{array}{l}\text { Out- } \\
\text { come }\end{array}$ \\
\hline 1 & NHL & MTX/HD AraC & CoNS & EBV & + & + & NS & - & \\
\hline 2 & AML & $7+3$ & CoNS & EBV & + & + & NS & - & \\
\hline 3 & $\mathrm{NHL}$ & $\mathrm{R}-\mathrm{CHOP}$ & CoNS & CMV & + & $\begin{array}{l}\text { Septic } \\
\text { shock }\end{array}$ & NS & - & \\
\hline 4 & AML & $7+3$ & CoNS & $\begin{array}{l}\text { EBV } \\
\text { HHV6 }\end{array}$ & + & + & NS & + & \\
\hline 5 & ALL & VRP-prolong & CoNS & - & + & + & NS & - & \\
\hline 6 & ALL & MOAD & CoNS & - & + & + & NS & + & \\
\hline 7 & APL & $\begin{array}{l}5+2+ \\
\text { ATRA }\end{array}$ & CoNS & - & + & + & $\begin{array}{l}\text { Catheter- } \\
\text { associated }\end{array}$ & - & \\
\hline 8 & CLL & COD & CoNS & - & + & + & NS & - & Lethal \\
\hline 9 & NHL & R-ICE & CoNS & - & + & + & $\begin{array}{l}\text { Catheter- } \\
\text { associated }\end{array}$ & - & \\
\hline 10 & ALL & $\begin{array}{l}\text { MOAD, } \\
\text { VRP-prolong }\end{array}$ & CoNS & - & + & + & Lungs & - & \\
\hline 11 & AML & "7+3" & $\begin{array}{l}\text { CoNS + } \\
\text { Rhodotor. }\end{array}$ & - & + & + & Lungs & + & Lethal \\
\hline 12 & AML & $\begin{array}{l}\text { Idarubicin+ } \\
\text { Cladribine }\end{array}$ & S.aureus & - & + & + & $\begin{array}{l}\text { Catheter- } \\
\text { associated }\end{array}$ & - & \\
\hline 13 & AML & $7+3$ & S.aureus & $\begin{array}{l}\text { EBV } \\
\text { HHV6 }\end{array}$ & + & + & NS & - & \\
\hline 14 & $\begin{array}{l}\text { CML, blast } \\
\text { crisis }\end{array}$ & $\begin{array}{l}\text { Imatinib } \\
7+3\end{array}$ & S.aureus & - & + & + & NS & - & \\
\hline 15 & APL & $\begin{array}{l}7+3, \\
\text { ATRA } \\
\end{array}$ & S.aureus & - & + & + & NS & - & \\
\hline 16 & MDS & Decitabine & S.aureus & - & + & + & NS & - & \\
\hline 17 & CML & $\begin{array}{l}\text { Hydrea, } \mathrm{Cy}- \\
\text { tosar }\end{array}$ & S.aureus & - & + & + & NS & - & \\
\hline 18 & $\begin{array}{l}\text { Multiple } \\
\text { myeloma }\end{array}$ & CVAD & S.aureus & - & + & + & NS & - & \\
\hline 19 & $\mathrm{NHL}$ & $\mathrm{R}-\mathrm{CHOP}$ & $\begin{array}{l}\text { Enterococcus } \\
\text { spp. }\end{array}$ & $\begin{array}{l}\text { CMV } \\
\text { EBV }\end{array}$ & + & + & Throat & - & \\
\hline
\end{tabular}

Notes: APL, acute promyelocytic leukemia; NS, not specified; Treatment regimens: HSCT, Hematopoietic stem cell transplantation;7+3, 5+2, Cytarabine+Doxorubicin; FC, Fludarabine+Cyclophosphamide; FCR, Fludarabine+Cyclophosphamide+Rituximab; R-CHOP, Rituximab+Cyclphosphamide+Doxorubicin+Vincristin+Prednisolon; FLAG, Filgrastim+Fludarabine+Cytarabine; MOAD, Methotrexate+Vincristin+L-Asparaginase+Dexamethasone; VRP-prolong, Vincristine+Doxorubicin+during induction, consolidation, and early intensification with high-dose Methotrexate; FCD, Fludarabine+Cyclophosphamide+ Dexamethasone; MTX/HD AraC, Methotrexate+ high-dose Cytarabine; COD, Cyclophosphamide+Vincristine+Dexamethasone; R-ICE, Rituximab+Ifosfamide+Carboplatin+Etoposide; CVAD, Cyclophasphamide+Vincristine+Doxorubicin+Dexamethasone. 
Etiological role of Gram-positive microbes is more discutable. As seen from Table 7, CoNS were most common Gram-positive microbes isolated. A universal recommendation for detection of the microbes in blood specimens is to administer multiple blood sampling. In most cases, we used a more practical and quite efficient recommendation based on the terms of in vitro bacterial outgrowth, e.g., the test is likely to be positive if it is detected at short terms of culture $(<3 \ldots 5$ days). Late outgrowth suggests an artifactual microbial contamination [1]. Based on these criteria and clinical data, we have suggested a sufficient role of CoNS in systemic inflammatory response for eleven patients with different hematological tumors following intensive cytostatic chemotherapy.

Interestingly, 4 of 11 patients with coagulase-negative bacteremia had a concomitant herpesvirus infection: two cases were associated with $\mathrm{EBV}$, and one, with CMV positivity. A combination of HHV6/EBV was found in one patient, thus potentially proving the immunocompromised condition in these cases. In four patients, we have found a constellation of three herpesvirus types, i.e., EBV, CMV, and HHV6. Therefore, a high ratio of viral and bacterial co-infections may be typical to a number of patients with proven sepsis after intensive cytostatic chemotherapy.

\section{Discussion}

Modern methods of leukemia treatment allow to sufficiently increase complete remission rates and to increase survival of the patients. The role of infectious complications following intensive leukemia therapy becomes increasingly high, due to improved diagnostics of infectious pathogens over last decade. Urgent diagnostics of these infections permits timely usage of specific therapy. Two decades ago, most pneumonia cases in such patients were classified as 'unknown origin' since full-scale PCR assays for viruses were not used, like as express diagnostics of bacterial cultures. Introduction of molecular biology testing allowed to extend opportunities of viral diagnostics in immunocompromised patients with leukemias and lymphoma [5].

We used real-time PCR approach covering the main set of respiratory pathogens. Application of this diagnostic set combined with bacteriological methods allowed to assess etiology of infectious processes in $62 \%$ of cases. In comparison group (leukemia patients without clinical signs of infections), the infectious agents were revealed in 7/35 (20\%) of the patients. In general, our data are in accordance with results by G.Gerna et al.[7], who performed their studies by similar scenario in the patients receiving lung transplants.

Noteworthy, development of respiratory infections in the patients under study was accompanied by rather common incidence (42\%) of herpesvirus detection, especially, CMV and EBV which are associated with immunosuppressive conditions. The data presented are confirming a significant role of viral pathogens, especially, herpesviruses, which are potential factors of immunosuppression and concomitant bacterial infections in leukemia patients. The data from second group of patients seem to confirm this finding. E.coli was commonly revealed in patients' blood.
Moraxella catarrhalis was associated with septicemia in two cases, both accompanied by herpesvirus activation. Previously, M.catarrhalis was considered a causal factor for otitis media, sinusitis, and conjunctivitis in children. Later on, a role of this microorganism was suggested for septicemias in acute leukemia patients $[8,12]$. Therefore, M.catarrhalis seems to play a distinct role in development of infectious complications in immunocompromised patients with oncohematological disorders $[10,14]$.

What concerns etiological significance of Gram-positive microorganisms in bacteremia, one should mind a high probability of skin contamination, e.g., with coagulase-negative staphylococci, thus increasing chances for false-positive results of hemocultures, due to the CoNS transfer during vein puncture. A possible role of CoNS in systemic inflammatory syndrome was assessed in $57.8 \%$ of hematological patients. Of them, 36\% exhibited EBV, CMV, or HHV6 in blood leukocytes. Hence, the observed viral co-infection may be a biological marker of a generalized immune suppression. Nevertheless, one should bear in mind a probable independent role of herpesviruses in pathogenesis of infectious complications.

In the present study, antibacterial therapy started with $\beta$-lactame antibiotics combined with fluoroquinolones, aminoglycosides, metronidazole. If required, the antimicrobial strategy was revised 48 to 72 hours later as based on clinical and microbiological data, applying carbapenems also combined with other anti-infectious drugs. Nevertheless, mortality rates in Gram-negative and Gram-positive sepsis comprised, respectively, $57 \%$ and $11 \%$. These patients suffered with severe primary malignancies, being mostly resistant to cytostatic treatment, with bulky disease and expressed immunosuppression due to drug-induced cytopenia.

One should mind a role of fungi in evolving infectious complications which may occur at any step of anticancer therapy, due to decreased innate immunity. Appropriate risk factor include neutropenia, damage to skin, intestinal mucosa, early administration of broad-spectrum antibiotics, glucocorticosteroids, immunosuppressive drugs that favor colonization with Candida spp. [9]. When treating these patients, we used Fluconazole, Voriconazole, or Caspofungin.

\section{Conclusion}

In summary, our data support a general viewpoint on regular monitoring of infectious pathogens upon intensive chemotherapy of oncohematological patients prone to both bacterial and viral infections. Severe infectious complications (pneumonia, sepsis) are often associated with fungal invasions, and herpesvirus reactivation.

In particular, our results suggest that different viruses, e.g., herpesviruses, may cause immunosuppression, or may serve as additional immunodeficiency markers predictive for bacterial infections at later terms. Most patients who developed severe infections (e.g., AML and NHL cases) are potential candidates for hematopoietic stem cell transplantation. Therefore, one should take into account their predisposition for infectious complications when planning HSCT for these patients. 


\section{Conflict of interests}

No conflict of interests is declared.

\section{References}

1. Souvenir D, Anderson DE Jr, Palpant S et al. Blood Cultures Positive for Coagulase-Negative Staphylococci: Antisepsis, Pseudobacteremia, and Therapy of Patients. J Clin Microbiol 1998; 36 (7): 1923-1926

2. Baker CN, Stocker SA, Culver DH et al. Comparison of E-test to agar dilution broth microdilution and agar diffusion susceptibility testing techniques by using a special challenge set of bacteria. J Clin Microbiol 1991; 29: 533-538.

3. Bessmeltsev SS, Abdulkadyrov KM. Multiple myeloma: The Physicians' Guide. Moscow: MK Publishers, 2016, 504 p. (In Russian)

4. Chebotkevich V, Kiseleva E, Stizhak N et al. Epidemiology and clinical characteristics of bloodstream infections in hematological cancer patients. Haematologica 2016; 101 (s1): 765 .

5. Chebotkevitch V, Volkov A. Community respiratory virus infections in patients with haematological malignancies // $17^{\text {th }}$ ECCMID, March 31 - April 3, 2007. Munich, Germany. Ab. 589

6. Dellinger RP, Levy MM, Rhodes A et al. Surviving sepsis campaign: international guidelines for management of severe sepsis and septic shock. 2012 Intensive Care Med 2013; 39 (2): 165-228.

7. Gerna G, Vitulo P, Rovida F, Lilleri D, Pellegrini C, Oggionni T, Campanini G, Baldanti F, Revello MG. Impact of human metapneumovirus and human cytomegalovirus versus other respiratory viruses on the lower respiratory tract infections of lung transplant recipients. J Med Virol 2006; 78 (3): 408-416.
8. Henny FC, Mulder CJ, Lampe AS, van der Meer JW et al. Branhamella catarrhalis septicaemia in a granulocytopenic patient. Infection 1984; 12(3):208-209.

9. Bhatt VR, Viola GM, Ferrajoli A. Invasive Fungal Infections in Acute Leukemia. Ther Adv Hematol. 2011; 2(4): 231-247.

10. Leszczycska K, Jakoniuk P, Sacha PT et al. Susceptibility of Branhamella catarrhalis to antibiotics. Med Dosw Mikrobiol 2004; 56: 231-237.

11. Moiseev SI, Nuia ML, Chebotkevich VN, Gonchar VA, Abdulkadyrov KM. Cytomegalovirus infection in practice of bone marrow transplantation. Terapevticheskyi Archiv 2002; 74 (7): 44-48. (In Russian)

12. Saito H, Anaissie EJ, Khardori N et al. Branhamella catarrhalis septicemia in patients with leukemia. Cancer 1988; 61 (11): 2315-2317.

13. Girmenia C, Menichetti F. Current epidemiology and prevention of infectious complications in cancer patients. European Oncology and Haemotology 2011; 7 (4): 270-277.

14. Sirwar SB, Indupalli AS, Pal R et al. Moraxella catarrhalis: an emerging pathogen in bronchopulmonary infections. Ann Trop Med Publ Health 2013; 6(1): 76-79.

15. Versalovic J, Carroll KC, Funke G, Jorgensen JH, Landry ML, Warnock DW. (Eds.). Manual of Clinical Microbiology, 10th Edition, Vol. 1, 2011, ASM Press. 


\title{
Инфекции кровотока и реактивация вирусов после интенсивной химиотерапии взрослых больных онкогематологического профиля
}

\author{
Виталий Н. Чеботкевич, Станислав С. Бессмельцев, Екатерина Е. Киселева, Наталья П. Стижак, \\ Елена И. Кайтанджан, Виталий В. Бурылев \\ Российский научно-исследовательский институт гематологии и трансфузиологии, Санкт-Петербург, Россия
}

\section{Резюме}

Интенсивная цитостатическая химиотерапия является стандартной стратегией лечения лейкозов и лимфом. В то же время такое лечение вызывает негативные эффекты, в том числе лимфопению, гранулоцитопению и повреждение тканевых барьеров, что ассоциировано с существенными рисками инфекционных осложнений, особенно - бактериальным сепсисом и виремией. Целью нашей работы было выявление бактериемии и фунгемии у онкогематологических больных после интенсивной химиотерапии и оценка потенциальной модифицирующей роли герпесвирусных инфекций.

Мы определяли частоту развития инфекционных осложнений и соответствующих этиологических факторов в 2 группах пациентов онкогематологического профиля, проходивших лечение в Российском институте гематологии и трансфузиологии, учитывая, в частности, случаи смешанных инфекций. Мазки из зева, венозная кровь, а также образцы мочи и мокроты отбирали для рутинных бактериологических и вирусологических исследований. Лейкоциты цельной крови тестировали на вирусы посредством ПЦР с применением стандартных протоколов.

В первой группе пациентов (85 случаев) проводили исследования на респираторные вирусные инфекции. Вирусы гриппа и парагриппа, респираторно-синцитиальный вирус (РСВ), риновирус, аденовирус определялись в крови у единичных пациентов. В то же время герпесвирусы выявлялись, в целом, в $42 \%$ случаев. В частности, ДНК вирусов простого герпеса, Эпштейна-Барр (ВЭБ) и цитомегаловируса (ЦМВ) в лейкоцитах крови обнаружены в 5.2\%, 26.3\%, и 10.5\%, соответственно. Вирусные инфекции в этой группе пациентов не были достоверно ассоциированы с положительными бактериологическими пробами.

Отдельно анализировали результаты в группе из 33 случаев доказанного сепсиса, которые выявили среди 64 пациентов. В целом, частота выявления Грам-позитивных микроорганизмов преобладала над Грам-негативными культурами $(69,2 \%$ и $30,8 \%$, соответственно). Однако соотношение выявленной Грам-негативной флоры повысилось с 23\% до $40 \%$ в период с 2002 по 2013 гг. (p<0,05). Коагулазо-негативные стафилококки (КНС) преобладали среди Грам-позитивных микроорганизмов, в частности, S. epidermidis и S. aureus, тогда как Enterobacteriaceae, в особенности, E.coli, были наиболее частыми Грам-негативными бактериями.

Представляет интерес, что у 4 из 11 пациентов с КНС-сепсисом отмечены сопутствующие герпесвирусные инфекции, а именно 2 случая были ассоциированы с ВЭБ; 1 - с ЦМВ и 1 - с герпесвирусом человека 6 типа и ВЭБ. Частая реактивация герпесвирусов может вызвать иммуносупрессию или быть дополнительным прогностическим признаком иммунодефицита в плане риска бактериальных инфекций в более поздние сроки. Поэтому в таких случаях следует учитывать предрасположенность к тяжелым инфекционным осложнениям при планировании трансплантацию гемопоэтических клеток этим больным.

\section{Ключевые слова}

Лейкозы, лимфомы, интенсивная химиотерапия, сепсис, виремия, сочетанные инфекции. . 